\title{
Doxycycline treatment of nongonococcal urethritis with special reference to T-strain mycoplasmas
}

\author{
A. LASSUS, R-L. PERKO, S. STUBB, R. MATTILA, AND E. JANSSON \\ From the Department of Dermatology and Venereology, University Central Hospital, and the Municipal \\ Bacteriological Laboratory, Aurora Hospital, Helsinki, Finland
}

The disease, or group of diseases, known as nongonococcal urethritis (NGU) is of very common occurrence, and, according to Lees (1951), only 50 per cent. of all cases with urethritis are of gonococcal origin. Despite extensive investigation, the cause of most cases of NGU is still unknown, and although the evidence supporting the view that it is a venereal disease is strong, proof awaits the discovery of the causative agent or agents and the demonstration of sexual transmission.

In some cases of NGU, there is an identifiable cause such as Trichomonas vaginalis, fungi, or mechanical and chemical irritants, but such cases form only a small proportion of the whole group and are of minor importance.

In the large majority of cases of NGU, the aetiology is still uncertain. An organism belonging to the trachoma/inclusion conjunctivitis group (TRIC agent) has been suspected to be the aetiological factor in some cases (Dunlop, Al-Hussaini, Garland, Treharne, Harper, and Jones, 1965), but there is no evidence so far that a TRIC agent is commonly associated with NGU, and no certainty that it is causal. The importance of the 'diphtheroids' found by Furness and Csonka (1966) in urethral washings from males with NGU has not been established. The Gram-negative bacillus called 'Haemophilus' vaginalis (later identified by Zinnemann and Turner (1963) as a Corynebacterium), which was recovered by Leopold (1953), was first suggested to be a cause of NGU and of nongonococcal vaginitis; but later authors have found little evidence to support this concept (Lapage, 1961).

The first isolation of a genital strain of mycoplasma in man was performed by Dienes and Edsall (1937), and mycoplasmas have since been found in a variety of genital disorders, including NGU. Serologically the strain has usually been found to be Mycoplasma hominis. The comparatively low incidence of $M$. hominis in patients with NGU and its relative frequency in healthy persons indicate that it is of minor importance as an aetiological agent of NGU. Shepard (1954) observed tiny colonies among the large colonies of mycoplasma cultivated from the urethra of a patient with NGU. This T-strain of mycoplasma has since been the subject of numerous investigations, and some workers (Shepard, 1956; Ford and DuVernet, 1963; Shepard, Alexander, Lunceford, and Campbell, 1964; Csonka, Williams, and Corse, 1966; Shepard, 1970) consider that $\mathrm{T}$-strain mycoplasmas play an active part in the aetiology of NGU, while others (Ingham, MacFarlane, Hale, Selkon and Codd, 1966; Black and Rasmussen, 1968; Fowler and Leeming, 1969) have? been unable to support this theory.

The treatment of NGU has also been extensively investigated (Table I). It has been found empirically that the tetracycline group of antibiotics is superior, while antibiotics affecting cell-wall synthesis, e.g. pencillin and cycloserine, fail to influence the natural course of NGU. Since T-strain mycoplasmas are resistant to the latter, this has been held as an evidence of their aetiological importance. In addition, erythromycin, which affects $\mathrm{T}$-strain mycoplasma in vitro (Shepard, Lunceford, and Baker, 1966), has been found to be effective in the treatment of NGU. Placebos have yielded cure rates of 14 to 31 per cent. (Table I, opposite).

In experiments in vitro, doxycycline* ( $\alpha-6-$ deoxytetracycline) has been found to be effective against mycoplasmas (Yamazi, Takahashi, Ohkuni, and Todome, 1969). Since doxycycline was found to be superior to other members of the tetracycline group (which are the most effective antibiotics against NGU), it was thought to be indicated in the treatment of NGU.

\section{Material and methods}

The series comprised 99 male patients who were treated for urethritis at the Out-Patient Department for Venereal Diseases, University Central Hospital, Helsinki. Only those with a definite urethral discharge were included in 
T A B L E I Rates of cure obtained with various modes of treatment of nongonococcal urethritis

\begin{tabular}{|c|c|c|}
\hline Therapy & $\begin{array}{l}\text { Percentage } \\
\text { cured }\end{array}$ & Author(s) and date \\
\hline Tetracycline & $62-90$ & $\begin{array}{l}\text { Willcox, 1955b; } \\
\text { Willcox, 1957; } \\
\text { Jelinek, 1957; } \\
\text { Csonka and Rosedale, 1962; } \\
\text { Holmes, Johnson, and Floyd, 1967; } \\
\text { Grimble, 1968; } \\
\text { Csonka and Spitzer, 1969; } \\
\text { Fowler and Leeming, } 1969 .\end{array}$ \\
\hline Cxytetracycline & $70-91$ & $\begin{array}{l}\text { Harkness, 1953; } \\
\text { Willcox, 1953; } \\
\text { Willcox, 1955a; } \\
\text { Gartman and Leibovitz, 1955; } \\
\text { Willcox, 1957; } \\
\text { Doyle, Gill, and Laird, 1957; } \\
\text { Jelinek, 1957; } \\
\text { Morton and Read, 1957 } \\
\text { Fowler, 1958. }\end{array}$ \\
\hline Chlortetracycline & $59-81$ & $\begin{array}{l}\text { Harkness, 1953; } \\
\text { Willcox, 1953; } \\
\text { Jensen, 1954; } \\
\text { Willcox, 1955a; } \\
\text { Gartman and Leibovitz, 1955; } \\
\text { Willcox, 1957; } \\
\text { Morton and Read, } 1957 .\end{array}$ \\
\hline $\begin{array}{l}\text { Demethylchlor- } \\
\text { tetracycline }\end{array}$ & $90-93$ & Csonka and Rosedale, 1962. \\
\hline Methacycline & 80 & Morton and Wray, 1966 \\
\hline Erythromycin & $52-72$ & $\begin{array}{l}\text { Willcox, 1955b; } \\
\text { Prebble, 1957; } \\
\text { Willcox, 1957; } \\
\text { Grimble, 1968; } \\
\text { Csonka and Spitzer, } 1969 .\end{array}$ \\
\hline Chloramphenicol & $31-78$ & $\begin{array}{l}\text { Harkness, 1953; } \\
\text { Willcox, 1953; } \\
\text { Gartman and Leibovitz, 1955; } \\
\text { Willcox, 1957; } \\
\text { Morton and Read, } 1957 .\end{array}$ \\
\hline Streptomycin & $38-70$ & $\begin{array}{l}\text { Harkness, 1953; } \\
\text { Willcox, 1953; } \\
\text { Gartman and Leibovitz, 1955; } \\
\text { Willcox, 1957; Doyle and } \\
\text { others, 1957; } \\
\text { Jelinek, 1957; } \\
\text { Morton and Read, 1957; } \\
\text { Fowler, 1958. }\end{array}$ \\
\hline Penicillin & $41-60$ & $\begin{array}{l}\text { Willcox, 1953; } \\
\text { Gartman and Leibovitz, 1955; } \\
\text { Willcox, 1957; } \\
\text { Morton and Morrison, } 1963 .\end{array}$ \\
\hline Ampicillin & 70 & Morton and Morrison, 1963. \\
\hline Sulphonamides & $22-90$ & $\begin{array}{l}\text { Babione and Graham, 1952; } \\
\text { Willcox, 1953; } \\
\text { Willcox, 1957; } \\
\text { Doyle and others, 1957; } \\
\text { Jelinek, 1957; } \\
\text { Morton and Read, 1957; } \\
\text { Fowler, 1958. }\end{array}$ \\
\hline Sigmamycin & 77 & Oates, 1958. \\
\hline Cycloserine & 25 & Csonka and others, 1966. \\
\hline Lincomycin & 25 & Csonka and Spitzer, 1969. \\
\hline Placebo & $14-31$ & $\begin{array}{l}\text { Jensen, 1954; } \\
\text { Willcox, 1957; } \\
\text { Doyle and others, 1957; } \\
\text { Holmes and others, } 1967 .\end{array}$ \\
\hline
\end{tabular}

the study. Neisseria gonorrhoeae and Trichomonas vaginalis were excluded by microscopical examination and culture in all cases. Clinical data on the patients are presented in Table II. The technique for the isolation of mycoplasmas has been described in another communication (Jansson, Lassus, Stubb, and Tuuri, 1971).

All patients received an initial dose of $200 \mathrm{mg}$. doxycycline and subsequent doses of $100 \mathrm{mg}$. per day for 4 consecutive days. All patients were re-examined 14 to 21 days after the beginning of the treatment. A patient was considered cured if there were no symptoms of urethritis and no microscopic signs of pyuria. If there were still symptoms and/or signs of urethritis, the patient was retreated with an initial dose of $200 \mathrm{mg}$. doxycycline and doses of $100 \mathrm{mg}$. per day for the next 10 days.

As controls, 38 sailors and 39 recruits with no signs of urethritis were investigated for $\mathrm{T}$-strain mycoplasmas, using the same technique as in the cases with NGU.

\section{Results}

Of the 99 patients with NGU, 59 (60 per cent.) had a positive culture of $T$-strain mycoplasma from the urethral discharge before treatment (Table II). T-strain mycoplasmas were also found in twenty of the 38 sailors without NGU (53 per cent.) and in nine of the 39 recruits (23 per cent.).

There were no great differences in degree of education? or employment status between the T-strain positive and T-strain negative patients with NGU. Neither was there any major difference in promiscuity (Table II).

Many of the patients with NGU had had earlier attacks, and approximately the same number had previously had gonorrhoea (Table II). Earlier attacks of NGU and gonorrhoea had occurred with equal frequency in both the $T$-strain positive and the $T$-strain negative cases.

The duration of urethritis before admission ranged from one day to more than one month. It was found that the T-strain positive patients often had NGU of shorter duration than the $T$-strain negative patients (Table II). Of the $59 \mathrm{~T}$-strain positive patients, 41 (70 per cent.) had noted the symptoms of urethritis within one week before coming to the hospital; the corresponding figure for $\mathrm{T}$-strain negative patients was nineteen out of forty (48 per cent.). Four of the T-strain positive patients ( 7 per cent.) and eleven (28 per cent.) of the T-strain negative patients had NGU of over 4 weeks' duration.

The clinical severity of NGU was estimated on the basis of the quality and amount of the urethral discharge, which was found to be slightly less profuse in the Tstrain negative cases. The difference was, however, of minor importance (Table II). The results of the doxycycline treatment are presented in Table III. Of the Tstrain positive patients 54 (92 per cent.), and of the Tstrain negative patients 38 ( 95 per cent.), were clinically cured 14 to 21 days after treatment was begun. In the cases of fourteen ( 26 per cent.) of the $54 \mathrm{~T}$-strain positive patients who were judged to be clinically cured, T-strain mycoplasmas could still be cultured from the urethral discharge; six of these fourteen had had earlier attacks of NGU. 
TABLE II Clinical data on 99 patients with nongonococcal urethritis

\begin{tabular}{|c|c|c|c|c|}
\hline \multirow[b]{2}{*}{ Data } & & \multirow{3}{*}{$\begin{array}{l}\text { Total } \\
\text { cases } \\
99 \\
26 \cdot 2\end{array}$} & \multicolumn{2}{|c|}{$T$-strain mycoplasma } \\
\hline & & & $\begin{array}{l}\text { Positive } \\
59\end{array}$ & $\begin{array}{l}\text { Negative } \\
40\end{array}$ \\
\hline Average age (yrs) & & & $27 \cdot 3$ & $24 \cdot 6$ \\
\hline Profession: & $\begin{array}{l}\text { Student } \\
\text { Academic degree } \\
\text { Office/sales worker } \\
\text { Skilled worker } \\
\text { Unskilled worker } \\
\text { Miscellaneous }\end{array}$ & $\begin{array}{r}27 \\
6 \\
11 \\
39 \\
10 \\
6\end{array}$ & $\begin{array}{r}17 \\
5 \\
7 \\
20 \\
7 \\
3\end{array}$ & $\begin{array}{r}10 \\
1 \\
4 \\
19 \\
3 \\
3\end{array}$ \\
\hline Civil status: & $\begin{array}{l}\text { Married } \\
\text { Divorced } \\
\text { Single }\end{array}$ & $\begin{array}{r}19 \\
3 \\
77\end{array}$ & $\begin{array}{c}12 \\
1 \\
46\end{array}$ & $\begin{array}{l}7 \\
2 \\
31\end{array}$ \\
\hline Number of consorts (within last $3 \mathrm{mths}$ ): & $\begin{array}{l}\text { Marital only } \\
\text { One regular only (patient unmarried) } \\
\text { One casual } \\
\text { More than one casual } \\
\text { None }\end{array}$ & $\begin{array}{r}10 \\
15 \\
35 \\
37 \\
2\end{array}$ & $\begin{array}{r}6 \\
9 \\
22 \\
21 \\
1\end{array}$ & $\begin{array}{r}4 \\
6 \\
13 \\
16 \\
1\end{array}$ \\
\hline $\begin{array}{l}\text { Duration of symptoms before admission } \\
\text { (days): }\end{array}$ & $\begin{array}{l}1-7 \\
8-28 \\
29\end{array}$ & $\begin{array}{l}60 \\
24 \\
15\end{array}$ & $\begin{array}{r}41 \\
14 \\
4\end{array}$ & $\begin{array}{l}19 \\
10 \\
11\end{array}$ \\
\hline Urethral discharge: & $\begin{array}{l}\text { Purulent } \\
\text { Muco-purulent } \\
\text { Slightly muco-purulent }\end{array}$ & $\begin{array}{l}18 \\
39 \\
42\end{array}$ & $\begin{array}{l}11 \\
26 \\
22\end{array}$ & $\begin{array}{r}7 \\
13 \\
20\end{array}$ \\
\hline Earlier infection: & $\begin{array}{l}\text { Nongonococcal urethritis } \\
\text { Gonococcal urethritis }\end{array}$ & $\begin{array}{l}36 \\
40\end{array}$ & $\begin{array}{l}19 \\
24\end{array}$ & $\begin{array}{l}17 \\
16\end{array}$ \\
\hline
\end{tabular}

TABLE III Results of doxycycline treatment of 99 patients with nongonococcal urethritis

\begin{tabular}{|c|c|c|c|c|}
\hline & & \multirow[t]{2}{*}{ Total cases } & \multicolumn{2}{|c|}{$T$-strain mycoplasma } \\
\hline \multicolumn{2}{|l|}{ Results of treatment } & & Positive & Negative \\
\hline \multirow[t]{2}{*}{$\begin{array}{l}\text { Total dose of } 600 \mathrm{mg} . \\
\text { doxycycline }\end{array}$} & $\begin{array}{l}\text { Cured } \\
\text { Still T-strain }+\end{array}$ & 92 (93 per cent.) & $\begin{array}{l}54 \text { (92 per cent.) } \\
14\end{array}$ & 38 (95 per cent.) \\
\hline & $\begin{array}{l}\text { Failed } \\
\text { Still T-strain }+\end{array}$ & 7 (7 per cent.) & 5 (8 per cent.) & 2 (5 per cent.) \\
\hline \multicolumn{2}{|c|}{$\begin{array}{l}\text { Re-treatment with } 1,200 \mathrm{mg} \text {. doxycycline } \\
\text { Cured }\end{array}$} & $\begin{array}{l}7 \\
4\end{array}$ & $\begin{array}{l}5 \\
3\end{array}$ & $\begin{array}{l}2 \\
1\end{array}$ \\
\hline \multicolumn{2}{|c|}{ Lost from the follow-up study } & 2 & 2 & $\mathbf{0}$ \\
\hline \multicolumn{2}{|c|}{ Contracted gonorrhoea during second follow-up period } & 1 & 0 & 1 \\
\hline
\end{tabular}

In five $T$-strain positive and two $T$-strain negative cases the doxycycline treatment failed. In four of the five initially $\mathbf{T}$-strain positive patients, the mycoplasma could still be recovered at re-examination. Three of the seven cases of treatment failure occurred in patients who had had earlier attacks of NGU. All seven were re-treated with doxycycline for 11 days and were called for reexamination 14 days after the re-treatment was started. Two of the patients, both with a positive T-strain culture after the first treatment, were lost from the follow-up study. One of the two T-strain negative patients had caught gonorrhoea in the meantime and had to be excluded from the follow-up study. The remaining four patients were all clinically cured and all had a negative result to $T$-strain culture at the second re-examination.

\section{Discussion}

Nongonococcal urethritis has a tendency to spontaneous remissions and recurrences, which cause 
difficulties in the interpretation of treatment results. Csonka (1965) therefore suggested that double-blind trials were the best way of demonstrating the effects of treatment, and that they should only be dispensed with if the therapeutic response to the tested agent was immediate and approached 90 to 100 per cent. efficacy. The only antibiotics which come close to meeting this requirement are the tetracyclines. As Table I shows, there are great variations in the failure rates in different investigations, even when the same antibiotic is used. This is due mainly to differences in the treatment schedules, and in the length of the follow-up period. The longer the follow-up period, the more difficult it is to judge correctly the treatment results, since spontaneous remissions and recurrences are more prone to interfere. The risk of re-infection and the loss of patients from observation also increase with the length of the follow-up period. As it is generally agreed that a successful treatment is one with an immediate response, we feel that the observation period should not exceed 3 weeks.

The results of the present study do not confirm the role of $\mathrm{T}$-strain mycoplasmas as aetiological agents in NGU, since the mycoplasma was found almost as frequently in sailors without symptoms of urethritis. However, most of the sailors had earlier had gonorrhoea, and sailors are known to be highly promiscuous. This indicates indirectly that $\mathrm{T}$-strain mycoplasmas are sexually transmitted, especially as these organisms were found much less frequently in the young recruits. The only difference between $T$-strain positive and $T$-strain negative cases in the present series of cases of NGU was that the urethritis of the former seemed to be more acute.

Doxycycline has been found to be highly effective against various infections, including gonoccocal urethritis (Lassus, 1968, 1970). The prolonged high serum levels of doxycycline and its high tissue concentrations (Fabre, Pitton, and Kunz, 1966), as compared to older tetracyclines, indicated that it would be more effective than these in the treatment of NGU. The treatment results were excellent in both $\mathrm{T}$-strain positive and $\mathrm{T}$-strain negative cases. The therapeutic response was immediate in the successful cases. The few patients who did not meet the criteria for cure 2 to 3 weeks after starting treatment could have had recurrences, or perhaps in some cases a re-infection. This is supported by the fact that a prolonged re-treatment brought about a clinical cure in those patients who could be further observed.

T-strain mycoplasmas could be recovered after treatment in a high proportion of patients in spite of a clinical cure. This agrees with the findings of
Csonka and Spitzer (1969) and Fowler and Leeming (1969). Smith, Friedewald, and Chanock (1967) suggested that mycoplasmas may be protected from the action of some antibiotics when they are associated with cells; they found that $M$. pneumoniae persisted in respiratory-tract secretions in some cases, despite a clinical cure after tetracycline treatment.

It may be concluded that doxycycline proved highly effective in the treatment of NGU, irrespective of the presence of $\mathrm{T}$-strain mycoplasmas in the urethral discharge.

\section{Summary}

The effect of treatment with $600 \mathrm{mg}$. doxycycline was observed in 99 patients with nongonococcal urethritis, 60 per cent. of whom had T-strain mycoplasmas in their urethral discharge. Cures were obtained in 92 per cent. of the T-strain positive cases, and in 95 per cent. of the T-strain negative cases. In 26 per cent. of the $T$-strain positive cases, mycoplasmas could still be recovered after treatment, despite clinical improvement.

\section{References}

Babione, R. W., and Graham, R. S. (1952) Amer. 护 Syph., 36, 480

Black, F. T., and RASMussen, O. G. (1968) Brit. F. vener. Dis., 44, 324

CsONKA, G. W. (1965) Ibid., 41, 1 and RosEDALE, N. (1962) Ibid., 38, 157 and SPITZER, R. J. (1969) Ibid., 45, 52

- Williams, R. E. O., and CoRse, J. (1966) Lancet 1,1292

Dienes, L., and Edsall, G. (1937) Proc. Soc. Exp. Biol. (N.Y.), 36, 740

Doyle, J. O., Gill, A. J., and LAIRD, S. M. (1957) Brit. f. vener. Dis., 33, 100

Dunlop, E. M. C., Al-Hussaini, M. K., Garland, J. A., Treharne, J. D., Harper, I. A., and Jones, B. R. (1965) Lancet, 1, 1125

Fabre, J., Pitton, J. S., and Kunz, J. P. (1966) Chemotherapia (Basel), 11, 73

FoRD, D. K., and DU VERNET, M. (1963) Brit. f. vener. Dis., 39, 18

FowLER, W. (1958) Ibid., 34, 107 and LeEMING, R. J. (1969) Ibid., 45, 287

FurNess, G., and CSONKA, G. W. (1966) Ibid., 42, 185

Gartman, E., and Leibovitz, A. (1955) Ibid., 31, 92

GrimbLe, A. S. (1968) Ibid., 44, 230

HARKNESS, A. H. (1953) Ibid., 29, 134

Holmes, K. K., Johnson, D. W., and Floyd, T. M. (1967) f. Amer. med. Ass., 202, 474

Ingham, H. R., MacFarlane, W. V., HaLE, J. H., SELKon, J. B., and CODD, A. A. (1966) Brit. F. vener. Dis., 42, 269

Jansson, E., Lassus, A., StubB, S., and TuURI, S. श (1971) Ibid., 47, 122

JeLINEK, G. (1957) Ibid., 33, 156 
Jensen, T. (1954) Amer. F. Syph., 38, 125

LAPAGE, S. P. (1961) Acta path. microbiol. scand., 52, 34

LAssus, A. (1968) Chemotherapy, 13, 366

- (1970) Ibid., 15, 125

LEES, R. (1951) Brit. F. vener. Dis., 27, 34

LEOPOLD, S. (1953) U.S. armed Forces med. F., 4, 263

MORTON, R. S. and MORRISON, A. I. (1963) Brit. f. vener. Dis., 39, 244 and READ, L. (1957) Ibid., 33, 223

and WRAY, P. M. (1966) Ibid., 42, 195

Prebrle, E. E. (1957) Ibid., 33, 43

OATES, J. K. (1958) Ibid., 34, 38

SHEPARD, M. C. (1954) Amer. F. Syph., 38, 113 (1956) f. Bact., 71, 362

- (1970) f. Amer. med. Ass., 211, 1335

-, AleXander, C. E., LunCEFord, C. D., and CAMPBELL, P. E. (1964) Ibid., 188, 729

- - LUNCEFORD, C. D., and BAKER, R. L. (1966) Brit. F. vener. Dis., 42, 21

Smith, C. B., Friedewald, W. T., and Chanock, R. M. (1967) New Engl. F. Med., 276, 1172

Willcox, R. R. (1953) Brit. F. vener. Dis., 29, 225

- (1955a) Ibid., 31, 89 (1955b) Ibid., 31, 186

(1957) Ibid., 33, 52

(1962) Ibid., 38, 72

Yamazi, Y., Takahashi, M., OHKunI, H., and Todome, Y. (1969) Chemotherapy (fapan), 17, 119

Zinnemann, K., and TuRner, G. C. (1963) F. Path. Bact., 85, 213

Le traitement de l'urétrite non gonococcique par la doxycycline et particulièrement en ce qui concerne les mycoplasmes de souche $T$

SOMMAIRE

On a noté les effets du traitement par $600 \mathrm{mg}$. de doxycycline chez 99 malades atteints d'urétrite non gonococcique, dont 60 pout cent avaient des mycoplasmes $T$ dans leur écoulement. La guérison fut obtenue dans 92 pour cent des cas avec présence de souche $T$ et dans 95 pour cent des cas négatifs. Dans 26 pour cent des cas positifs pour la souche $T$, les mycoplasmes purent continuer à être trouvés après traitement, malgré l'amélioration clinique. 